\title{
Comparative anatomical study of the leg's nerves of Cebus (barbed capuchins) with baboons, chimpanzees and modern humans ${ }^{1}$
}

\author{
Tainá de $\mathrm{Abreu}^{2}$, Gabriel A. Pfrimer², Roqueline A.G.M.F. Aversi-Ferreira², Lorraine \\ D. Brandão ${ }^{2}$, Rafael S. Maior ${ }^{3}$, Hisao Nishijo ${ }^{4}$ and Tales A. Aversi-Ferreira ${ }^{2,4 *}$
}

\begin{abstract}
Abreu T., Pfrimer G.A., Aversi-Ferreira R.A.G.M.F., Brandão L.D., Maior R.S., Nishijo H. \& Aversi-Ferreira T.A. 2012. Comparative anatomical study of the leg's nerves of Cebus (barbed capuchins) with baboons, chimpanzees and modern humans. Pesquisa Veterinária Brasileira 32(Supl.1):113-117. Laboratory of Anthropology, Biochemistry, Neuroscience and Behavior of Primates, University Federal of Tocantins, Avenida NS 15, 109 North, Palmas, T0 77001-090, Brazil. E-mail: aversiferreira@gmail.com

The anatomical comparative studies among the primates are important for the investigation of ethology, evolution, taxonomy, and comprehension of tools by hominoids. Especially the anatomical knowledge of Cebus contributes to conservation of the species, and to development of surgical procedures and clinical treatments of these animals, as they frequently are victims of automobile accidents. Recent anatomical studies came to a wrong conclusion regarding behavioral traits of Cebus, ascribed to few data available in previous literature. Therefore, to provide anatomical data and to support the other sciences related to anatomy, and to develop surgical and/or clinical procedures, we described the nerves of the legs of Cebus foccusing on their position and trajectory, as wll as innerved muscles, and compared these results with those of humans and other primates. Eight adult capuchin specimens were used for this study. The anatomical comparative study of the leg's nerves of Cebus demonstrated that, in general, structural organization of the nerves is similar among the four primates analyzed here (Cebus, chimpanzees, baboons and humans), which might be attributed to the fact that the all four primates have similar body structures. However, nerve trajectory and muscles innervation in Cebus was more similar to baboons.
\end{abstract}

INDEX TERMS: Nerves, pelvic members, leg, capuchin monkey, barbed capuchins, Cebus, primates.

RESUMO.- [Estudo anatômico comparativo dos nervos da perna de Cebus (macaco-prego) com babuínos, chimpanzés e humanos modernos.] Os estudos anatômicos comparativos entre os primatas são importantes para pesquisas associadas com a etologia, evolução, taxonomia e compreensão dos usos de ferramentas pelos hominídeos. Especificamente, o conhecimento anatômico sobre Cebus contribui para sua própria conservação e para o desenvol-

\footnotetext{
${ }^{1}$ Received on July 13, 2012.

Accepted for publication on December 1, 2012

${ }^{2}$ Laboratório de Antropologia, Bioquímica, Neurociências e Comportamento de Primatas (Labinecop), Universidade Federal do Tocantins (UFT), Avenida NS15, 109 Norte, Palmas, T0 77001-090, Brazil. *Corresponding author: aversiferreira@gmail.com

${ }^{3}$ Departamento de Ciências Fisiológicas, Instituto de Biologia,, Centro de Primatas, e Laboratório de Neurociências e de Comportamento, Universidade de Brasília, Brasília, DF 70910-900, Brazil.

${ }^{4}$ Department of Physiology, School of Medicine and Pharmaceutical Sciences, System Emotional Science, University of Toyama, Sugitani 2630, Toyama, 930-0194, Japan.
}

vimento de procedimentos cirúrgicos e tratamentos clínicos destes animais, pois são frequentemente vítimas de acidentes automobilísticos. Recentemente, estudos sobre características comportamentais de Cebus indicaram conclusões erradas sobre sua anatomia, o que pode ser atribuído aos poucos dados disponíveis sobre a anatomia desses animais na literatura especializada. Portanto, para fornecer dados anatômicos e fornecer suporte para as outras ciências relacionadas com a anatomia e também desenvolver procedimentos cirúrgicos e/ou clínicos, foram descritos os nervos das pernas de Cebus com enfoque sobre a posição, a trajetória e os músculos inervados, e comparar esses resultados com os dos humanos modernos e outros primatas. Oito espécimes adultos de macacos-prego foram usados para este estudo. 0 estudo anatômico comparativo dos nervos da perna de Cebus demonstrou que, em geral, a organização estrutural dos nervos é semelhante entre os quatro primatas aqui analisados (Cebus, chimpanzés, babuínos e humanos modernos), o que pode ser atribuído ao fato de 
que os quatro primatas terem estruturas corporais semelhantes. No entanto, a trajetória dos nervos e a inervação dos músculos em Cebus o aproximam dos babuínos.

TERMOS DE INDEXAÇÃO: Nervos, membros pélvicos, perna, macacos-prego, Cebus, primatas.

\section{INTRODUCTION}

The primate Cebus living abundantly in South American (Auricchio 1995) has high cephalization index, high memory capacity, and high manual dexterity for tool use, which characteristics until now are seen only in the old world primates (Aversi-Ferreira et al. 2010).

Previous studies reported, using Cebus, 1) anatomy of the thoracic members in the shoulder, arm (Aversi-Ferreira et al. 2007a, 2007b, 2007c), and forearm (Aversi-Ferreira et al. 2005a, 2005b, 2006, 2010, 2011b, Marin et al. 2009, $2010), 2)$ anatomy of the pelvic members, thigh's nerves (Aversi-Ferreira et al. 2011a), retus femoralis muscle (Amado et al. 2011), 3) neuroanatomy (Watanabe 1982, Watanabe \& Madeira 1982, Borges, Ferreira \& Caixeta 2010, Pereira-de-Paula et al. 2010), 4) behavior and tool use (Aversi-Ferreira et al. 2011a, 2010, Resende \& Ottoni 2002), 5) cortical physiology (Lima, Fiorani \& Gattass 2003), 6) cephalization index (Areia 1995, Byrne 2000), and 7) memory capability (Tavares \& Tomaz 2002). Recently wild capuchins were observed to fish for termites using twigs, which is a behavior that have been reported until now only in chimpanzees (Souto et al. 2011).

The anatomical comparative studies among the primates are important to researches associated with ethology, evolution, taxonomy and comprehension of tool uses by hominoids. Specifically, the anatomical knowledge of Cebus contributes to conservation of the animal, to development of surgical procedures and clinical treatments of these animals because these animals are frequently victims of automobile accidents (Kindlovits 1999, Aversi-Ferreira et al. 2011a,) in urban environment where some groups live.

Anatomical studies of peripheral nervous system indicates innervation of muscular groups that, possibly, are similar to different clades of primates, which allow evaluating behavioral activities of the animals how arborous and/ or terrestrial habits are in terms of anatomy of the muscles (Aversi-Ferreira et al. 2011b). Similarity between innerved muscles of given animals in the taxon is a characteristic of phylogenetic proximity between the given species (Aversi-Ferreira et al. 2005b).

However, the morphological data of this genus in previous literatures are too few to evaluate behavioral activity of this animal in terms of anatomical data. Indeed, a lack of these data should result in confusion of evaluation of motor activity of the body structures used in tool use (Aversi-Ferreira et al. 2010, 2011a, 2011b). It has been reported that innervation and numbers of nerve fibers are associated with the level of dexterity and control of these structures by the animal (Machado 2006).

Recently, anatomical studies made a wrong conclusion regarding behavioral traits of Cebus (Aversi-Ferreira et al. $2010,2011 b)$, because few data were available in previous li- teratures, and the studies did not encompass the all anatomical regions. Therefore, in the present study, to provide anatomical data to support the other sciences related to anatomy and to develop surgical and/or clinical procedures, we investigated the nerves of the legs of barbed capuchins foccusing on their positions and trajectory, and innerved muscles, and compared these results with those of humans (Standring 2008) and other primates (Swindler \& Wood 1973).

\section{MATERIALS AND METHODS}

Eight adult capuchin specimens (Cebus) were used weighing 1-3 $\mathrm{kg}$. No animal was killed for the purposes of this study; four of them died accidentally in their natural habitats and were acquired from anatomical collection of the Antropology, Biochemistry, Neuroscience and Behavior of Primates Laboratory (Labinecop) from the Federal University of Tocantins, Palmas, Tocantins. The remaining animals belonged to the Brazilian Institute of Environment and Renewable Natural Resources (IBAMA) archive and were donated to the University of Uberlandia in the 1970's. This work was approved by the Institutional Ethical Committee from the Federal University of Goiás (CoEP-UFG 81/2008, authorization from the IBAMA number 15275).

The animals obtained from IBAMA arrived frozen and after the trichotomy with a razor blade, they were incubated in water at room temperature for 10-12 hr; then received, from the femoral artery, perfusion by $10 \%$ of formaldehyde with $5 \%$ of glycerin for fixation. The animals were conserved in $10 \%$ of formaldehyde, in covered opaque cubes, to avoid the penetration of light and the evaporation of formaldehyde.

Dissection was performed with emphasis on the nerves of the leg, and registered with a digital camera and schemes. The nomenclature, whenever it is possible, was applied to those used in human anatomy (The Federative Committee on Anatomical Terminology, 1998). The anatomical positions of the nerves usually referred to those in human. When position was different from that in humans, this was clearly indicated in text. The data collected were analyzed and compared with the patterns in human, chimpanzee and baboon species.

\section{RESULTS}

Sciatic nerve. The sciatic nerve is placed in the posterior thigh region and is the largest nerve until now studied in the barbed capuchins. In the distal third of thigh, it branches into the fibular and tibial nerves. However, its division could occur in any area from the sacral plexus and distal third of thigh. The sural medial nerve is a branch from the sciatic nerve.

Tibial nerve. In Cebus, the tibial nerve (Fig. 1, 3 and 6) is a branch from the sciatic nerve passing through the posterior region of the leg. After through the popliteus fossa in the proximal third, it penetrates between two heads of the gastrocnemius muscle, and travels deeply to the soleus muscle, laterally to the tibial flexors of the fingers and medially to the tibial posterior muscle. In the distal part of the leg, the tibial nerve divides into two branches, the medial and lateral plantar nerves.

This trajectory was observed in $81.25 \%$ of analyzed species, and in $8.75 \%$ was observed a variation of the branching in the medial and lateral plantar nerves that divide at the plantar region. 

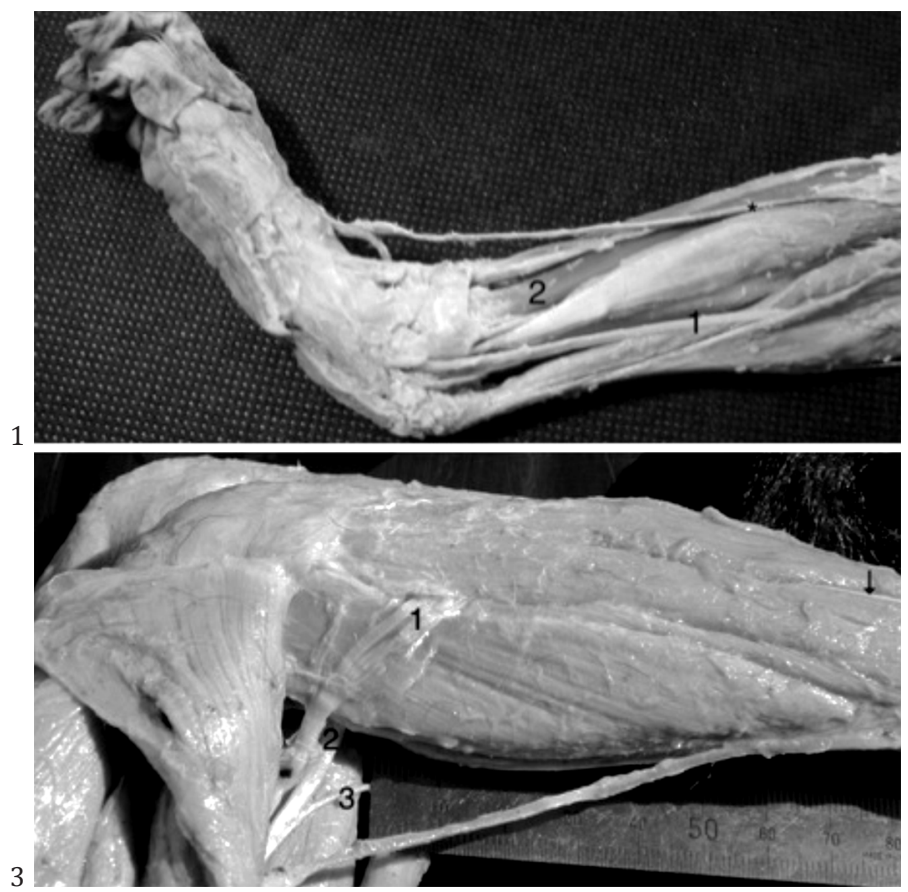

Fig.1. A view of medial aspect of the right leg of Cebus. The number 1 indicates the tibial nerve, 2 the tibial bone, and the asterisk the saphena magna vein. $0.9 x$.

Fig.3. A view of lateral aspect of the right leg of Cebus. The number 1 to 3 indicates the fibular common nerve, the tibial nerve, and the medial cutaneous nerve, respectively. An arrow indicates the fibular superficial nerve. $1.25 \mathrm{x}$.

These nerves branch to innervate the muscles in the posterior region of the legs. These are the tibiofibular, popliteus, gastrocnemius, tibial posterior, tibial flexor of the fingers (equivalent to the flexor longus digitorum to humans), and flexor fibular of the fingers (flexor hallucis longus).

Medial sural cutaneous nerve. The medial sural cutaneous nerve (Fig. 2 and 6) emerges from the sciatic nerves passes between two heads of the gastrocnemius muscle in the proximal part of the leg, and travels to the posterior part of this muscle. In the distal third of the leg, its divides into two terminal branches to innervate the lateral region of the foot.

Common fibular nerve. The common fibular nerve is a branch from the sciatic nerve. It travels through the popliteus

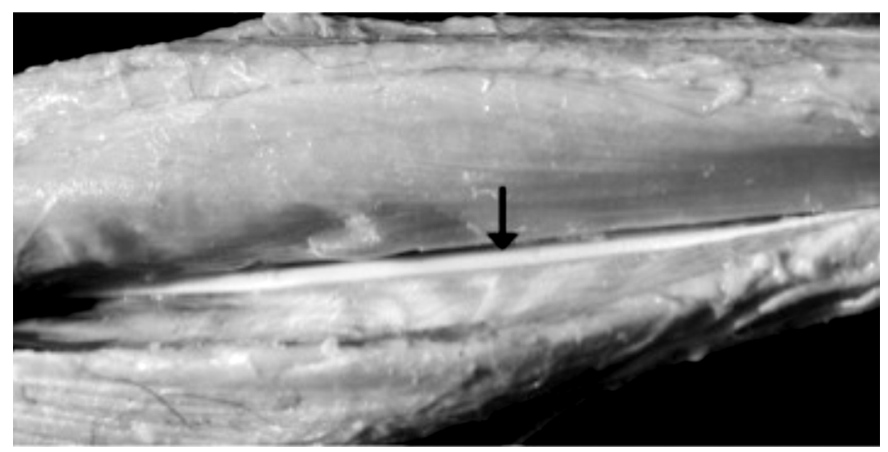

Fig.5. A view of lateral-posterior aspect of the right leg of the $\mathrm{Ce}$ bus. The arrow indicates the fibular deep nerve. $1.25 \mathrm{x}$

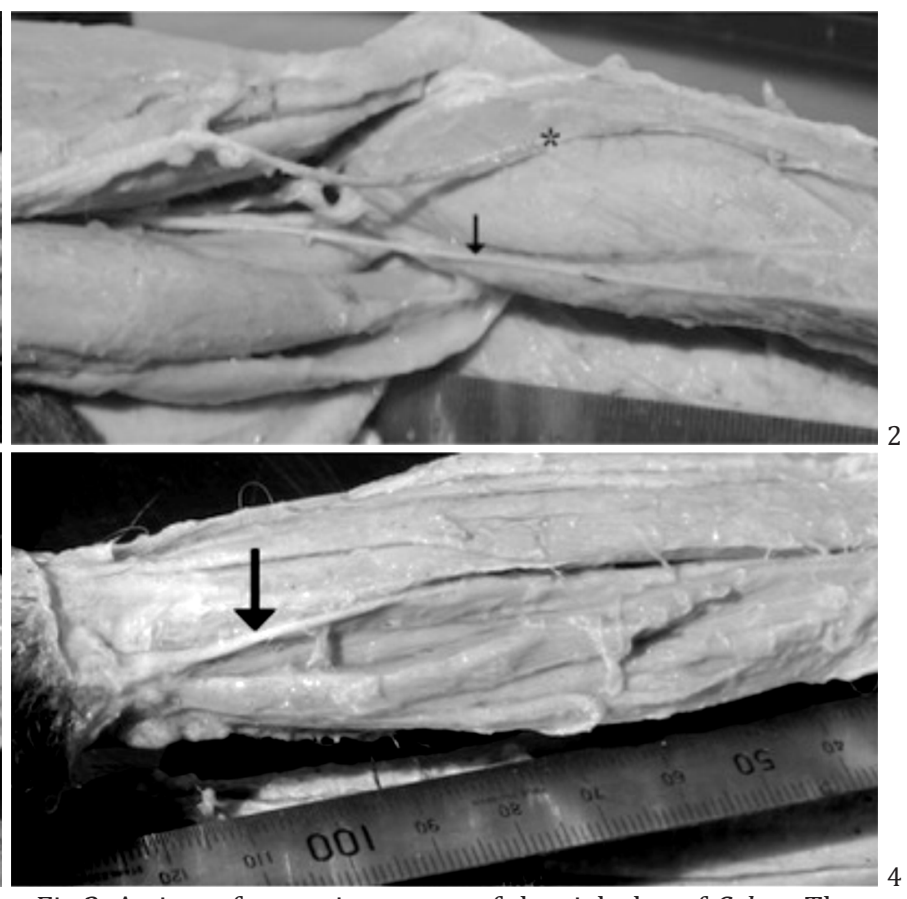

Fig.2. A view of posterior aspect of the right leg of Cebus. The arrow indicates the medial sural cutaneous nerve, and the asterisk the saphena parva vein. $0.9 x$.

Fig.4. A view of anterior-lateral aspect of the right leg of Cebus. The arrow indicates the fibular superficial nerve. $1.25 \mathrm{x}$.

fossa, and is placed medially to distal portion of the femoral biceps muscle. Then, it travels to a lateral aspect of the leg, and passes on dorsal surface of the lateral head of the gastrocnemius muscle, where it divides into terminal branches, i.e., the superficial and deep fibular nerves (Fig. 3 and 6).

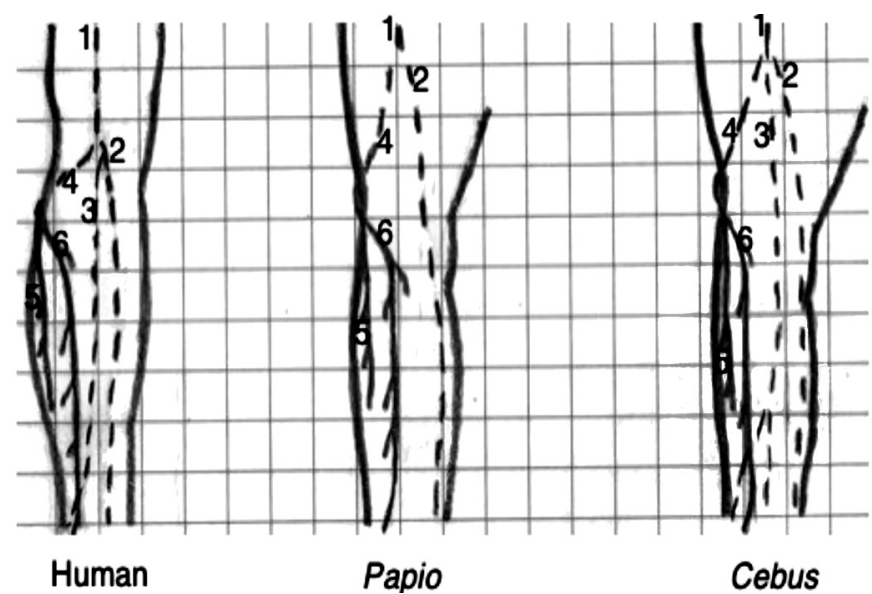

Fig.6. Schemes of the anterior view of the right legs of Homo, $\mathrm{Pa}$ pio and Cebus, in which the principal nerves and the similarity of arrangement of these nerves among these primates are indicated. The number 1 indicates the sciatic nerve, 2 the tibial nerve, 3 the medial sural cutaneous nerve, 4 the fibular common nerve, 5 the fibular superficial nerve, and 6 the fibular deep nerve. The dashed lines indicate the posterior view and the continuous line the anterior. Schemes were made without considering the scale. 
Superficial fibular nerve. The fibular superficial nerve (Fig.4 and 6) is a branch from the fibular common nerve. It immediately penetrates the fibers of the fibular longus and extensor digitorum longus muscles, and travels under the skin in the distal third of the leg, and goes superficially to the extensor retinaculum. Then, it divides into various branches to the muscles in the dorsal foot; innervate the fibular longus, fibular brevis, extensor digitorum longus and dorsal foot muscles.

Deep fibular nerve. In the proximal third of the leg, the deep fibular nerve (Figs. 5 and 6) penetrates the fibers of the fibular longus and extensor digitorum longus muscles, and travels medially to the extensor digitorum longus muscle. Then, it travels under the extensor hallucis longus muscle and goes through under the retinaculum of the extensors muscles. The muscular branches of this nerve innervate the extensor digitorum longus, extensor hallucis longus, tibialis anterior and tibial accessory muscles.

Saphenous nerve. This nerve is a thin branch from the femoral nerve that runs along with the saphenous artery.

\section{DISCUSSION}

Comparison of the individual nerves among the four primates

The description of trajectory and innervation of the tibial nerve of chimpanzee and baboons are reported by Swindler $\&$ Wood (1973). For human anatomy, we refer to the most new anatomical literature by Stranding (2008). Both the studies indicated similarity to barbed capuchins, in general. However, locations of the final ramification of the tibial nerve are different; ramification occurs in the medial third of the leg in Cebus, while in other primates it occurs below and posteriorly to the medial malleolus. The innerved muscles are similar among chimpanzees, baboons and Cebus, except the tibiofibular muscle, that exists in both the Old World primates (chimpanzees, baboons) and barbed capuchins, and is innerved by the tibial nerve (Swindler \& Wood, 1973), while this muscle does not exist humans (Testut \& Laterjet 1958, Standring 2008). On the other hand, both baboons and Cebus have the fibular digiti quinti muscle.
The medial sural cutaneous nerve in barbed capuchins has similar distributions, innervations and localizations to those in non-humans primates. However, those anatomical characteristics are different from those in humans where in the medium third of the leg it merges with the fibular common nerve to form the sural nerve (Standring 2008), different from that in humans. In the baboons and chimpanzees the fibular common nerve travels under the femoral biceps muscle (Swindler \& Wood, 1973), what was observed in Cebus but in humans its route is more posterior and medial to this muscle in distal portion located in popliteus fossa (Standring 2008).

Trajectory of the fibular superficial nerve is identical among the all primates studied here (Swindler \& Wood 1973) including Cebus. However, in baboon, the fibular quinti digit muscle is innerved by the fibular superficial nerve (Swindler \& Wood 1973), how was verified in Cebus, but this muscle is vestigial in chimpanzee and absent in humans. Differently to other primates, in barbed capuchins, the fibular superficial nerve emits the branch to the extensor digitorum longus muscle.

The trajectory of the deep fibular nerve is similar among the all primates studied here (Swindler \& Wood 1973, Standring, 2008). However, it innervates the additional muscles in Cebus i.e. the accessory tibial (Table 1).

\section{Comprehensive comparison}

In general, the comparison of the results indicates that the innervation of the muscles is similar among the four primates. However, there are minor differences between the non-human primates (Cebus chimpanzees, and baboons) and humans; the common existence of the fibular quinti digiti muscles in the non-human primates. Another minor differences indicate that nerve trajectory and muscles innervation in barbed capuchins was similar to baboons. Indeed, in others studies on comparative anatomy of thoracic members was reported higher similarity between baboons and Cebus rather than chimpanzees and modern humans, except the abductor pollicis longus and extensor pollicis brevis in barbed capuchins that are more similar

Table 1. Comparison of muscles innervation of the leg in Cebus with chimpanzees, baboons and humans

\begin{tabular}{|c|c|c|c|c|}
\hline Nerves & $\begin{array}{l}\text { Cebus (barbed } \\
\text { capuchins) }\end{array}$ & Chimpanzees & Baboons & Modern humans \\
\hline Tibial & $\begin{array}{l}\text { Gastrocnemius, soleus, } \\
\text { plantaris, popliteus, tibia- } \\
\text { lis posterior, tibiofibu lar, } \\
\text { flexor tibial digi torum, } \\
\text { flexor tibial muscles }\end{array}$ & $\begin{array}{l}\text { Gastrocnemius, soleus, } \\
\text { plantaris, popliteus, tibia- } \\
\text { lis posterior, tibiofibu lar, } \\
\text { fibular flexor digitorum } \\
\text { muscles }\end{array}$ & $\begin{array}{l}\text { Gastrocnemius, soleus, plan- } \\
\text { taris, popliteus, tibialis pos- } \\
\text { terior, tibiofibular, fibular } \\
\text { flexor digitorum muscles }\end{array}$ & $\begin{array}{l}\text { Gastrocnemius, soleus, plan- } \\
\text { taris, popliteus, tibialis pos- } \\
\text { terior, flexor hallucis longus, } \\
\text { flexor longus digitorum }\end{array}$ \\
\hline Medial cutaneous & Terminal branches on foot & Terminal branches on foot & Terminal branches on foot & Terminal branches on foot \\
\hline Common fibular & $\begin{array}{l}\text { Fibular superficial and } \\
\text { deep nerves, lateral head } \\
\text { of gastrocnemius }\end{array}$ & $\begin{array}{l}\text { Fibular superficial and } \\
\text { deep nerves }\end{array}$ & $\begin{array}{l}\text { Fibular superficial and deep } \\
\text { nerves }\end{array}$ & $\begin{array}{l}\text { Fibular superficial and deep } \\
\text { nerves }\end{array}$ \\
\hline Superficial fibular & $\begin{array}{l}\text { Fibular longus and bre- } \\
\text { vis, extensor digitorum } \\
\text { longus, fibular digiti quin- } \\
\text { ti muscles }\end{array}$ & $\begin{array}{l}\text { Fibular longus and bre- } \\
\text { vis, fibular digiti quinti } \\
\text { muscles }\end{array}$ & $\begin{array}{l}\text { Fibular longus and brevis, } \\
\text { fibular digiti quinti mus- } \\
\text { cles }\end{array}$ & Fibular longus and brevis \\
\hline Deep fibular & $\begin{array}{l}\text { Tibialis anterior and ac- } \\
\text { cessory, extensor digito- } \\
\text { rum longus, extensor hal- } \\
\text { lucis longus muscles }\end{array}$ & $\begin{array}{l}\text { Tibialis anterior, exten- } \\
\text { sor digitorum longus, ex- } \\
\text { tensor hallucis longus } \\
\text { muscles }\end{array}$ & $\begin{array}{l}\text { Tibialis anterior, extensor } \\
\text { digitorum longus, extensor } \\
\text { hallucis longus muscles }\end{array}$ & $\begin{array}{l}\text { Tibialis anterior, extensor di- } \\
\text { gitorum longus, extensor hal- } \\
\text { lucis longus, fibular tertius } \\
\text { muscles }\end{array}$ \\
\hline
\end{tabular}


to chimpanzees and modern humans (Aversi-Ferreira et al. 2010, 2011b). The similarity between Cebus and baboons is consistent with the behavioral and structural similarity between these 2 primates; similar body structures, terrestrial quadrupedal locomotion, presence of tail, and arborous habit (Aversi-Ferreira et al. 2005a, 2005b, 2006, 2007a, 2007b, 2007c, 2009, 2010, 2011b).

Kindlovits (1999) in the book "Clinical and Therapeutics in Neotropical Primates" cited previous studies for clinical and surgical applications to these primates, but scarcely cited the anatomical data. Therefore, it is difficult to choose the best surgical access and perform correct clinical procedures in general, especially in Cebus although this monkey is the most common neotropical primates in veterinary clinics in Brazil and South America (Aversi-Ferreira et al. 2011a).

Choice of surgical access in the Cebus's leg is important to avoid cutting in the proximal lateral region of the leg because the fibular common nerve travels superficially after the exit from the biceps femoral muscle. Furthermore, we must pay attention to the posterior region because the cutaneous sural medial nerve travels in the superficial position between the gastrocnemius heads proximally, and after medium third this nerve crosses laterally and obliquely.

\section{CONCLUSIONS}

The anatomical comparative study of the leg's nerves in barbed capuchins demonstrated that, in general, the patterns of organization is identical among the four primates analyzed here since the primates have similar body structures and consequently the muscles are positioned in the similar sequence.

However, nerve trajectory and muscles innervation in Cebus was similar to baboons, as reported in previous studies of the thoracic members.

Acknowledgements.- This study was supported by Core Research for Evolutional Science and Technology, Japan Science and Technology Agency, Japan, the Japan Society for the Promotion of Science Asian Core Program, and the Ministry of Education, Science, Sports and Culture, Grant-in-Aid for Scientific Research (A) (22240051), and by the National Council of Technology and Development (CNPq), Brazil. The funders had no role in study design, data collection and analysis, decision to publish, or preparation of the manuscript.

\section{REFERENCES}

Amado L.T.M., Sousa G.C., Silva D.C.O., Silva Z., Júnior R.B., Neto M.A.F., Lizardo F.B., Santos L.A., Barros R.A.C. \& Santos A.Q. 2011. Anatomia da fixação proximal do músculo reto femoral em humanos, Cebus apella e Alouatta guariba. Pubvet. 5 (12).

Areia M. 1995. Encefalização. Instituto Antropológico de Coimbra, Coimbra. 45p. (Apostila)

Auricchio P. 1995. Primatas do Brasil. Terra Brasilis, São Paulo. 168p.

Aversi-Ferreira T.A., Aversi-Ferreira R.A.G.M.F., Gouvêa-e-Silva Z.S.L.F. \& Penha-Silva N. 2005a. Estudo anatômico de músculos profundos do antebraço de Cebus apella (Linnaeus, 1766). Acta Sci. Biol. Sci. 27(3):297301.

Aversi-Ferreira T.A., Silva M.S.L., Paula J.P., Silva L.F.G. \& Penha-Silva N. 2005b. Anatomia comparativa dos nervos do braço de Cebus apella: descrição do músculo dorso epitroclear. Acta Sci. Biol. Sci. 27(3):291-296.

Aversi-Ferreira T.A., Vieira L.G., Pires R.M., Silva Z. \& Penha-Silva N. 2006.
Estudo anatômico dos músculos flexores superficiais do antebraço no macaco Cebus apella. Biosci. J. 22(1):139-144.

Aversi-Ferreira T.A., Paula P.J., Silva M.S.L. \& Silva Z. 2007a. Anatomy of the arteries of the arm of Cebus libidinosus (Rylands et al., 2000) monkeys. Acta Sci. Biol. Sci. 29(3):247-254.

Aversi-Ferreira T.A., Pereira-de-Paula J., Prado Y.C.L., Lima-e-Silva M.S. \& Mata J.R. 2007b. Anatomy of the shoulder and arm muscles of Cebus libidinosus. Braz. J. Morphol. Sci. 24(2):63-74.

Aversi-Ferreira T.A., Pereira-de-Paula J., Lima-e-Silva M.S., Prado Y.C.L. \& Silva Z. 2007c. Estudo anatômico das artérias do ombro de Cebus libidinosus (Rylands, 2000; Primates, Cebidae). Ciênc. Anim. Bras. 8(2):273284.

Aversi-Ferreira T.A. 2009. Comparative anatomical description of forearm and hand arteries of Cebus libidinosus. Int. J. Morphol. 27 (1):219-226. (Online)

Aversi-Ferreira T.A., Diogo R., Potau J.M., Bello G., Pastor J.F. \& Ashraf Aziz M. 2010. Anatomical study of the forearm extensor muscles of Cebus libidinosus (Rylands et al. 2000; Primates, Cebidae), modern humans, and other primates, with comments on primate evolution, phylogeny, and manipulatory behavior. Anat. Rec. 293:2056-2070.

Aversi-Ferreira R.A.G.M.F., Marin K.A., Carneiro-e-Silva F.O. \& Aversi-Ferreira T.A. 2011a. Comparative anatomy of the thigh nerve of Cebus libidinosus (Rylands et al. 2000). Pesq. Vet. Bras. 31(3):261-266.

Aversi-Ferreira T.A., Maior R.S., Carneiro-e-Silva F.O., Aversi-Ferreira R.A.G. M.F., Tavares M.C., Nishijo H. \& Tomaz C. 2011b. Comparative anatomical analyses of the forearm muscles of Cebus libidinosus (Rylands et al. 2000): manipulatory behavior and tool use. Plos One 6:1-8.

Borges K.C.M., Ferreira J.R. \& Caixeta L.F. 2010. The prefrontal areas and cerebral hemispheres of the neotropical Cebus apella and their correlations with cognitive processes. Dement Neuropsychol. 4(3):181-187.

Byrne R. 2000. Evolution of primate cognition. Cogn Sci. 24(3):543-570.

Kindlovits A. 1999. Clínica e Terapêutica em Primatas Neotropicais. Editora UFJF, Juiz de Fora. 264p.

Lima B., Fiorini L. \& Gattass R. 2003. Modulation by context of a scene in monkey anterior infratemporal cortex a sacadic eye movement task. Anais Acad. Bras. Ciênc. 75(1):71-76.

Machado A. 2006. Neuroanatomia Funcional. 4르 ed. Editora Atheneu, Rio de Janeiro.

Marin K.A., Carneiro e Silva F.O., Carvalho A.A.V., Nascimento G.N.L., Prado Y.C.L. \& Aversi-Ferreira T.A. 2009. Anatomy of the nervous of forearm and hand of Cebus libidinosus (Rylands, 2000). Int. J. Morphol. 27(3):635642.

Pereira-de-Paula J., Prado Y.C.L., Tomaz C. \& Aversi-Ferreira T.A. 2010. Anatomical study of the main sulci and gyri of the Cebus libidinosus brain (Rylands 2000). Neurobiologia 2(2):65-78.

Resende B.D. \& Ottoni E.B. 2002. Brincadeira e aprendizagem do uso de ferramentas em macacos-prego (Cebus apella). Estudos de Psicologia $7(1): 173-180$

Souto A., Bione C.B.C., Bastos M., Bezerra M.B., Fragazy D. \& Schiel N. 2011. Critically endangered blonde capuchins fish for termites and use new techniques to accomplish the task. Biol. Lett. 7(4):532-535.

Standring S. 2008. Gray's anatomy: the anatomical basis of clinical practice. Churchill Livingstone, London. 1576p.

Swindler D.R. \& Wood C.D. 1973. An Atlas of Primate Gross Anatomy. University of Washington Press, Washington. 370p.

Tavares M.C.H. \& Tomaz C.A.B. 2002. Working memory in capuchin monkeys (Cebus apella). Behav. Brain Res. 131(1/2):131-137.

Testut L. \& Latarjet A. 1958. Tratado de Anatomia Humana. 9a ed. Salvat, Barcelona. 766p.

Watanabe I. 1982. Comparative study of the medulla oblongata, pons, mesencephalon and cerebellum of the tufted capuchin (Cebus apella Linnaeus, 1758). Revta Odontol. Unesp 11:13-25.

Watanabe I. \& Madeira M.C. 1982. The anatomy of the brain of the tufted capuchin (Cebus apella Linnaeus, 1758). Revta Odontol. Unesp 11:5-12. 